\title{
Editorial (ED)
}

\section{Autonomous Ships from the Editor's Perspective}

The number of computer-aided systems on boards is gradually increasing and the number of people on board is decreasing as a result of the technological development. For example, a cargo ship with a crew of 20-25 people can now safely operate with fewer people. While speaking about the technological development, it is appropriate to underline two concepts: big data and the internet of things (IoT). Big data is briefly defined as the emergence of reliable new information, depending on how much information having about anything. The IoT is defined as a network where objects can connect to each other or to larger systems. These two concepts take technological development to a different level and play a major role especially in the development of autonomous systems. We can say that autonomous and remotely controlled ship technology also emerged on the basis of these two concepts.

The concept of autonomous ship includes fundamental technologies such as autonomous navigation, automatic berthing / unberthing, remotely-monitored engine, equipment and loading operations and automatic communication between ships. It covers a wide range from ships which are fully unmanned or can be remotely-controlled from land-based virtual bridges, and ships with systems that alert the operator to a possible pre-conflict or help optimize operations.

Although the idea that ships could sail with computer support was originally based on the 1970s, research has gained momentum especially since the beginning of 2010s. The first unmanned surface vehicle project launched by South Korea in 2011 and the Maritime Unmanned Navigation through Intelligence in Networks (MUNIN) project launched in 2012 and financed by the European Union emerged as the first concrete steps. New developments about the topic are experienced day by day in the international arena with the lead of the United States of America (USA), United Kingdom (UK), China, Denmark, Finland, South Korea, Japan, Norway and Singapore. While the governmental institutions make efforts especially on the establishment of legal regulations and standards, private institutions carry out studies on technological development. For example, UK Maritime Autonomous Systems Regulatory Working Group (MASRWG) has developed a code of conduct for autonomous ships. Norway has established the Norwegian Forum for Autonomous Ships (NFAS) to support and develop the concept of unmanned maritime transport with the participation of government agencies and industrial organizations. On the other hand, the Chinese Classification Society (CSS), ClassNK and DNV GL have initiated studies to set standards and to make recommendations for the revision of international regulations. From the private organizations, especially RollsRoyce, Google, Intel, Norway-based Yara and Kongsberg, Finland-based FinFries and Mitsui O.S.K. Lines (MOL) spends effort to develop the technology. In addition to the consortiums established by governments and companies alone or together, 
There is an international group established to strengthen the relationship network between organizations interested in the field of autonomous and unmanned ships research. The group, called the International Network for Autonomous Ships (INAS) and whose secretariat is run by Norway, consists of 16 countries including USA, UK, China, Denmark, Finland, South Korea, Japan and Australia and European Space Agency (ESA) and the European Maritime Safety Agency (EMSA). From the Turkey perspective, Dokuz Eylul University, İstanbul Technical University and Yıldız Technical University conducts research on the subject and companies such as ASELSAN and SANMAR are working on the subject.

It is predicted that the autonomous or remotely controlled ships may commence operations sooner than expected due to the rapid development of the technology. IMO has taken the issue to its agenda taking this possibility into consideration. The 98th meeting (MSC 98) held by the IMO Maritime Safety Committee (MSC) in June 2017 is the first committee meeting in which the concept of unmanned and autonomous ships came to the agenda. In the meeting, which was taking into consideration the rapid development of unmanned vessels in the future, it was suggested that the requirements of Maritime Autonomous Surface Ships (MASS) should be investigated under the headings of safety, security, environment and efficiency and discussed on revision of existing regulations. As a result of the MSC 98, it was decided that a work program should be initiated at the next meeting to define an "autonomous ship" definition and a regulatory scope on existing IMO regulations. At the 99th committee meeting (MSC 99) held in May 2018, the committee initiated a study on how safe, secure and environmentally sensitive MASS operations can be conducted. At this meeting, the Committee approved the methodology and work plan for the regulatory scoping study, which includes details such as the MASS definition and autonomous degrees. MASS was defined by the Committee as "a vessel capable of operating independently of varying degrees of human interaction". At the 100th meeting (MSC 100) held in December 2018, the committee completed the first regulatory scoping activities for autonomous ships. IMO instruments to be discussed within the scope of the scoping exercise planned to be completed in 2020 include safety, watchkeeping standards, search and rescue, security, traffic rules, loading and ship balance. The committee also initiated a working group to establish guidelines for the testing of autonomous ships.

As a result, the concept of autonomous and unmanned ships may be the hottest research topic in the maritime industry, nowadays. International institutions and organizations intensively carry out their initiatives and activities in order to gain competitive advantage in this new field. Turkey needs to be active not to miss the rapid progress in autonomous ship technology. Similar to the international activities mentioned above, launching some initiatives in Turkey is extremely important in terms of having a significant pie-share of the new technology in the future. Forming a research group consisting of universities, government agencies and private organizations and taking an active role as a member of international associations such as the INAS will contribute to be among the countries producing technologies for autonomous ship concept. As an editorial board, we plan to include more frequently the studies on autonomous ships and artificial intelligence applications in JEMS.

\section{Editor}

Prof. Dr. Selçuk NAS

Associate Editor

Remzi Fıșkın 


\section{Editörden (ED)}

\section{Editör Perspektifinden Otonom Gemiler}

Teknolojik gelişim ile birlikte gemilerde yer alan bilgisayar destekli sistem sayısı giderek artmakta ve bu duruma bağlı olarak gemide bulunan insan sayısı kademeli olarak azalmaktadır. Örneğin önceleri 20-25 kişi arası mürettebat bulunduran bir yük gemisi artık çok daha az kişi ile operasyonlarını emniyetli bir şekilde yürütebilmektedir. Teknolojik gelişim demişken burada iki kavramın altını çizmek yerinde olacaktır: büyük veri (big data) ve nesnelerin interneti (internet of things - IoT). Büyük veri kısaca, herhangi bir şey hakkında ne kadar çok bilgi sahibi olunduğuna bağlı olarak güvenilir yeni bilgilerin ortaya çıması olarak tanımlanmaktadır. Nesnelerin interneti ise, nesnelerin birbirleriyle veya daha büyük sistemlerle bağlant kurabildiği bir iletişim ağı olarak ifade edilmektedir. Bu iki kavram teknolojik gelişimi farklı bir boyuta taşımakta ve özellikle otonom sistemlerin gelişmesinde büyük rol oynamaktadır. Otonom ve uzaktan kontrol edilebilen gemi teknolojisinin de bu iki kavram temelinde ortaya çıtığını söyleyebiliriz.

Otonom ve uzaktan kontrol edilebilen gemi kavramı; otonom seyir, otomatik yanaşma/ ayrılma, uzaktan takip edilebilen makine, teçhizat ve yükleme operasyonları ve gemiler arası otomatik haberleşme gibi birçok otomasyon uygulamayı içeren bir alandır. Tamamen insansız veya karatabanlı sanal köprüüstünden uzaktan kontrol edilebilen gemilerden, operatörü olası bir çatışma öncesi uyaran veya operasyonları optimize etmeye yardımcı sistemlere sahip gemilere kadar geniș bir alanı kapsamaktadır.

Gemilerin bilgisayar desteği ile seyir yapabileceği fikri ilk olarak 1970'li ylllara dayansa da, özellikle 2010'lu yılların başından itibaren araştırmalar ivme kazanmıştır. 2011 yılında Güney Kore tarafından başlatılan insansız suüstü aracı projesi ve 2012 yılında başlatılan ve Avrupa Birliği tarafindan finanse edilen "Maritime Unmanned Navigation through Intelligence in Networks (MUNIN)" projesi ilk somut adımlar olarak ortaya çıkmıştır. Uluslararası arenada konu üzerine Amerika Birleşik Devletleri (ABD), Birleşik Krallık, Çin, Danimarka, Finlandiya, Güney Kore, Japonya, Norveç, Singapur gibi ülkelerin başı çekmesi ile her geçen gün yeni gelişmeler yașanmaktadır. Devlet kurumları özellikle yasal düzenlemeler ve standartların belirlenmesi üzerine çaba harcarken, özel kuruluşlar teknolojik olarak gelişimin sağlanması üzerine çalışmalar yürütmektedirler. Örneğin, Birleşik Krallık Deniz Otonom Sistemleri Yasal Düzenleme Çalışma Grubu otonom gemiler için yürütme ve uygulama kodu geliştirmiştir. Norveç ise, devlet kurumları ve sanayi kuruluşları iştiraki ile insansız deniz taşımacılığı kavramını desteklemek ve geliştirmek amacıyla Norveç Otonom Gemiler Forumu kurmuştur. Diğer taraftan China Classification Society (CSS), ClassNK ve DNV GL gibi klas kuruluşları ise standartların belirlenmesi ve uluslararası regülasyonların revizyonu için önerilerde bulunmak amacıyla çalışmalar bașlatmıştır. Özel kuruluşlara baktı̆̆ımızda ise özellikle Rolls-Royce, Google, Intel, Norveç merkezli Yara ve Kongsberg, Finlandiya merkezli FinFerries ve Japonya merkezli Mitsui O.S.K. Lines (MOL) gibi firmalar öne çlkmaktadır. Devletlerin ve firmaların tek başına veya 
bir araya gelerek oluşturdukları birlikteliklere ek olarak, otonom ve insansız gemiler araştırma alanına ilgi duyan organizasyonlar arasındaki ilişki ağını güçlendirmek amacıyla kurulmuş uluslararası bir yapı bulunmaktadır. Otonom Gemiler için Uluslararası İlişki Ağı (INAS) olarak isimlendirilen ve sekretaryası Norveç tarafından yürütülen bu grup içinde, ABD, Birleşik Krallık, Çin, Danimarka, Finlandiya, Güney Kore, Japonya ve Avustralya gibi ülkelerin de yer aldığı toplam 16 ülke, Avrupa Uzay Ajansı ve Avrupa Deniz Emniyeti Ajansı yer almaktadır. Türkiye özelinde ise Dokuz Eylül Üniversitesi, İstanbul Teknik Üniversitesi ve Yıldız Teknik Üniversitesi'nin konu üzerine araştırmalar yürütmektedir. Diğer taraftan ASELSAN A.Ş. ve SANMAR gibi firmalar da konu üzerine çalışmalar yapmaktadır.

Teknolojinin hızla ilerlemesi ile otonom veya uzaktan kontrol edilebilir gemilerin tahmin edilenden daha yakın zamanda faaliyetlerine başlayabileceği öngörülmektedir. Bu ihtimali göz önünde tutan IMO da konuyu gündemine almıştır. IMO Deniz Emniyeti Komitesi (MSC)'nin Haziran 2017'de gerçekleştirdiği 98. toplantı (MSC 98), insansız ve otonom gemi kavramının gündeme geldiği ilk komite toplantısı olma özelliğini taşımaktadır. Ortaya çıkan hızlı gelişimin dikkate alındığı toplantıda, otonom gemiler (Maritime Autonomous Surface Ships - MASS) ile ilgili emniyet, güvenlik, çevre ve verimlilik başlıkları altında gereklerin araştırılması ve mevcut düzenlemelerin revizyonu üzerine tartışılması gerektiği ileri sürülmüştür. MSC 98 sonucunda, "otonom gemi" tanımı ve mevcut IMO düzenlemeleri üzerine düzenleyici bir kapsam belirlenmesi için bir sonraki toplantıda bir çalışma programının başlatılması gerektiğine karar verilmiştir. Mayıs 2018'de gerçekleștirilen 99. toplantıda (MSC 99) ise komite, MASS operasyonlarının ne kadar emniyetli, güvenli ve çevreye duyarlı olarak gerçekleştirilebileceği üzerine bir çalışma başlatmıştır. Komite bu toplantıda, MASS tanımı ve otonom dereceleri gibi detayları da içeren düzenleyici kapsam belirleme çalışması için oluşturulan metodoloji ve çalışma planını onaylamıştır. Komite tarafından MASS "değişken derecelerde insan etkileşiminden bağımsız olarak faaliyet gösterebilen bir gemi” olarak tanımlanmıştır. Aralık 2018'de gerçekleştirilen 100. toplantıda (MSC 100) ise komite, otonom gemiler için başlattığı düzenleyici kapsam belirleme çalışmalarının ilkini tamamlamıştır. 2020'de tamamlamayı planladığı kapsam belirleme çalışmaları dâhilinde görüşülmesi gereken IMO enstrümanları arasında emniyet, vardiya standartları, arama kurtarma, güvenlik, trafik kuralları, yükleme ve gemi dengesi gibi düzenlemeler bulunmaktadır. Komite bu oturumda aynı zamanda, otonom gemilerin testleri ve denemeleri için kılavuz oluşturulması için bir çalışma grubu da başlatmıştır.

Sonuç olarak, otonom ve insansız gemi konsepti günümüzde denizcilik endüstrisinin belki de en sıcak araştırma konusu durumundadır. Uluslararası kurum ve kuruluşlar bu yeni alanda rekabet avantajını elde edebilmek amacıyla girişimlerini ve faaliyetlerini yoğun bir şekilde sürdürmektedirler. Otonom gemi teknolojisi ile ilgili hızlı bir ilerlemenin kaydedildiği günümüzde Türkiye'nin de aktif olarak girişimlerde ve faaliyetlerde bulunması gerekmektedir. Türkiye'de de yukarıda örneklendirilen uluslararası faaliyetlere benzer girişimleri hayata geçirmenin ileride sahip olacağımız pasta payı açısından son derece önemlidir. Devlet kurumları, özel kuruluşlar ve üniversitelerden oluşan bir araştırma grubu oluşturmak ve INAS gibi uluslararası birliklere üye olarak aktif rol almak, Türkiye'nin otonom gemi konsepti için teknoloji üreten ülkeler arasına girmesi ve önemli bir konum elde etmesi açısından katkı sağlayacaktır. JEMS yönetimi olarak özellikle otonom gemi ve uygulamaları ile yapay zekâ uygulamaları üzerine hazırlanmış olan çalışmalara dergimizde daha sık yer vermeyi planlıyoruz.

\section{Editör}

Prof. Dr. Selçuk NAS

Yardımcı Editör

Remzi FIŞKIN 